\title{
New nitric oxide donors based on ruthenium complexes
}

\author{
C.N. Lunardi ${ }^{1,2}$, R.S. da Silva ${ }^{1}$ and L.M. Bendhack ${ }^{1}$ \\ ${ }^{1}$ Laboratório de Farmacologia, Departamento de Física e Química, Faculdade de Ciências Farmacêuticas \\ de Ribeirão Preto, Universidade de São Paulo, Ribeirão Preto, SP, Brasil \\ ${ }^{2}$ Faculdade Ceilândia, Universidade de Brasília, Brasília, DF, Brasil \\ Correspondence to: L.M. Bendhack and C.N.Lunardi, Laboratório de Farmacologia, Departamento de \\ Física e Química, Faculdade de Ciências Farmacêuticas de Ribeirão Preto, USP, 14040-903 Ribeirão \\ Preto, SP, Brasil \\ Fax: +55-16-3602-4880. E-mail: bendhack@usp.br and clunardi@unb.br
}

\begin{abstract}
Nitric oxide (NO) donors produce NO-related activity when applied to biological systems. Among its diverse functions, NO has been implicated in vascular smooth muscle relaxation. Despite the great importance of NO in biological systems, its pharmacological and physiological studies have been limited due to its high reactivity and short half-life. In this review we will focus on our recent investigations of nitrosyl ruthenium complexes as NO-delivery agents and their effects on vascular smooth muscle cell relaxation. The high affinity of ruthenium for NO is a marked feature of its chemistry. The main signaling pathway responsible for the vascular relaxation induced by NO involves the activation of soluble guanylyl-cyclase, with subsequent accumulation of cGMP and activation of cGMP-dependent protein kinase. This in turn can activate several proteins such as $\mathrm{K}^{+}$ channels as well as induce vasodilatation by a decrease in cytosolic $\mathrm{Ca}^{2+}$. Oxidative stress and associated oxidative damage are mediators of vascular damage in several cardiovascular diseases, including hypertension. The increased production of the superoxide anion $\left(\mathrm{O}_{2}^{-}\right)$by the vascular wall has been observed in different animal models of hypertension. Vascular relaxation to the endogenous NO-related response or to NO released from NO deliverers is impaired in vessels from renal hypertensive $(2 \mathrm{~K}-1 \mathrm{C})$ rats. A growing amount of evidence supports the possibility that increased NO inactivation by excess $\mathrm{O}_{2}^{-}$may account for the decreased NO bioavailability and vascular dysfunction in hypertension.
\end{abstract}

Key words: Nitric oxide donor; Ruthenium complex; Nitrovasodilator; Vasodilatation

Presented at the IV Miguel R. Covian Symposium, Ribeirão Preto, SP, Brazil, May 23-25, 2008.

Research supported by FAPESP (\#04/09884-0) and CNPq (\#550265/2007-4).

Received August 5, 2008. Accepted January 12, 2009

\section{Introduction}

Endothelium dysfunction that leads to nitric oxide (NO) deficiency is present in several cardiovascular diseases (1). The discovery that NO is involved in multiple physiological and pathophysiological processes has promoted a large amount of pharmacological research into the design of new drugs that are capable of influencing NO production, directly and/or indirectly, for therapeutic purposes. In particular, the so-called NO donor drugs could have an important therapeutic effect on the treatment of many cardiovascular diseases such as angina and hypertension. The classic nitrovasodilators organic nitrate and nitrite esters, including nitroglycerin, amyl nitrite, isosorbide dinitrate, isosorbide 5-mononitrate and nicorandil, have been used in the treatment of cardiovascular diseases for many years (2).

NO donors produce NO-related activity when applied to biological systems, so they are mainly suited to either mimic an endogenous NO-related response or substitute an endogenous NO deficiency (1). NO is also the pharmacological principle of a number of drugs collectively termed 
nitrovasodilators, which are clinically used to control hypertensive crisis, protect patients from attacks of angina pectoris, and unload the heart during acute heart failure. Numerous other compounds, including NONOates, are available for the experimental generation of $\mathrm{NO}(3,4)$. Several NO donors have been used in clinical settings for decades (e.g., nitroglycerin and sodium nitroprusside). However, the growing interest in NO physiology since the mid 1980's has led to the development of a variety of new NO donors that offer several advantages over conventional NO donors $(1,5)$. Recently, several new metal complexes have been studied as NO donors or scavengers, including nitrosyl ruthenium complexes, nitrite complexes and related species (6-17).

The chemistry of metal nitrosyl complexes has taken on added significance in recent years because of the important role involving transition metal in the biological process of NO, as well as the possibility of producing thermodynamically stable and kinetically labile species (18-20). Such strategies have focused on the development of pharmacological substances capable of releasing $\mathrm{NO}$ at specific rates in tissues, in order to overcome NO deficiency. NO scavengers that reduce NO levels where excessive production is observed have also been designed. In recent years, there has been increasing interest in the chemistry of ruthenium complexes and their suitability as potential pharmaceutical agents because of their usually low cytotoxic characteristics $(10,21)$. Ruthenium (II) and ruthenium (III) are the most commonly employed ions and they are generally surrounded by six coordination spheres.

The high affinity of ruthenium for NO is a marked feature of its chemistry. Because this system has proven to be an NO donor agent under external stimulation, a large number of ruthenium complexes are currently being inves- tigated. Compared with the existing NO-donor drugs, this system has the advantage that $\mathrm{NO}$ could be released at a specific biological target. Although several nitrosyl ruthenium complexes have been synthesized and their chemical and physicochemical properties have been described, only few examples involve the above-discussed pharmacological aspects. In the present report, we will focus our attention on the compounds shown in Figure 1. A strategy that we have adopted in the design of nitrosyl ruthenium complexes is to bind ruthenium (II) with ligands that confer high thermodynamic stability and also water solubility to the resulting complex.

The co-ligands (L) in Figure 1 are named 1,4,8,12tetraazacyclopentadecane ([15]aneN $\mathrm{N}_{4}$ ) (I); 2,2'-bipyridine (bpy) (II) and 1,2-benzoquinonediimine-5-carboxylate (bdqiCOO) (III). Species (I) and (III) are characterized by a $\left\{\mathrm{Ru}^{\mathrm{II}}\right.$ $\left.\mathrm{NO}^{+}\right\}^{3+}$ bond, while compound (II) consists of $\left\{\mathrm{Ru}^{\mathrm{II}}-\mathrm{NO}{ }^{0}\right\}^{2+}$. All the species are stable at physiological $\mathrm{pH}$, although at $\mathrm{pH} \geq 9.0$ equilibrium with an appreciable amount of nitrite bound to ruthenium (II) takes place, as depicted in Equation 1.

$\left[\mathrm{RuL}_{5} \mathrm{NO}^{3+}+2 \mathrm{OH}^{-} \leftrightarrow\left[\mathrm{RuL}_{5}(\mathrm{NO})_{2}\right]^{+}+\mathrm{H}_{2} \mathrm{O}\right.$

(Equation 1)

Compounds (I) and (III) produce NO under light irradiation (Equation 2) or reducing medium (Equation 3) while compound (II) is an NO donor only under light stimulation.

$\left[\mathrm{RuL}_{5} \mathrm{NO}^{3+} \mathrm{hv} \rightarrow\left[\mathrm{RuL}_{5}\left(\mathrm{H}_{2} \mathrm{O}\right)\right]^{3+}+\mathrm{NO}\right.$

(Equation 2)

$\left[\mathrm{RuL}_{5} \mathrm{NO}^{3+}+\mathrm{e}^{-} \rightarrow\left[\mathrm{RuL}_{5}\left(\mathrm{H}_{2} \mathrm{O}\right)\right]^{2+}+\mathrm{NO}\right.$

(Equation 3)

On the basis of these properties, we have performed a series of pharmacological assays with these nitrosyl ruthe-

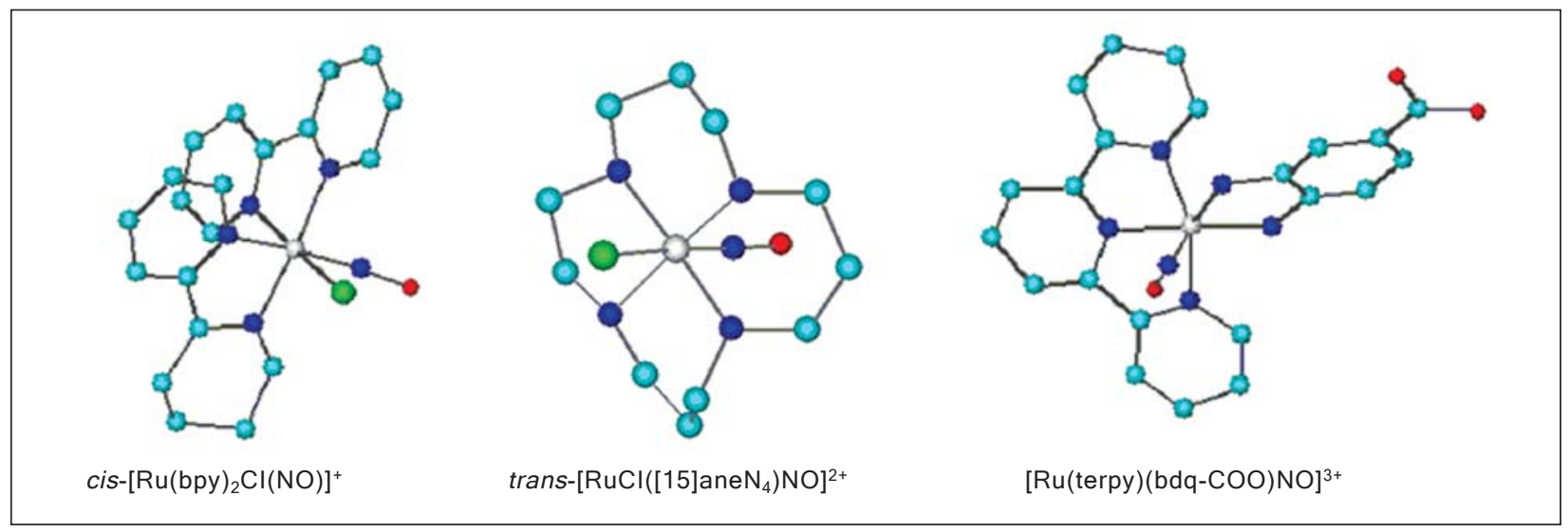

Figure 1. Molecular structure of cis- $\left[\mathrm{Ru}(\mathrm{bpy})_{2} \mathrm{Cl}(\mathrm{NO})\right]^{+}$, trans- $[\mathrm{RuCl}([15] \mathrm{aneN} 4) \mathrm{NO}]^{2+}$ and $[\mathrm{Ru}(\text { terpy })(\mathrm{bdq}-\mathrm{COO}) \mathrm{NO}]^{3+}(\mathrm{silver}=$ ruthenium, dark blue = nitrogen, light blue = carbon, and red = oxygen; hydrogen atoms have been omitted in the structure). 
nium complexes as new NO donor species. Our results suggest a new class of metal-based drugs.

\section{Nitrosyl ruthenium complex is an NO donor that induces rat aorta relaxation}

The mechanism by which $\mathrm{NO}$ induces relaxation is the subject of much investigation. When the signaling molecule NO enters a vascular smooth muscle cell, it activates an enzyme called guanylyl cyclase, which produces the second messenger 3'5'guanosine-monophosphate (cGMP) $(22,23)$. Guanylyl cyclase is a heterodimer that consists of two subunits, termed $\alpha$ and $\beta$, which are linked by disulfide bonds, and it has a prosthetic heme group covalently bound to the heterodimer $(23,24)$. NO activates cGMP synthesis by binding to the heme group, leading to the conversion of guanosine triphosphate to cGMP. cGMP activates a serine/threonine kinase, the cGMP-dependent protein kinase $G(P K G)$, leading to the phosphorylation of key regulatory proteins (25). PKG activation has been associated with isoform-specific autophosphorylation, which results in changes in the properties of the enzyme, including increased sensitivity to cyclic nucleotides and increased constitutive activity $(26,27)$. An increase in cellular cGMP levels occurs in response to the activation of the membrane guanylyl-cyclase or more commonly by activation of soluble guanylyl-cyclase by NO (28). Numerous studies have inferred activation of PKG in response to diverse ligands, presumably downstream of $\mathrm{NO}$ production (29). NO has two signaling pathways, a cGMP-dependent one and a cGMP independent one, which could directly activate $\mathrm{K}^{+}$channels (30).

\section{Potassium channel}

Potassium channels are a group of transmembrane proteins that have several functions $(31,32)$. The activation of $\mathrm{K}^{+}$channels in the vascular smooth muscle cell membrane stimulates $\mathrm{K}^{+}$efflux, membrane hyperpolarization, decreased $\mathrm{Ca}^{2+}$ entry through voltage-operated channels, and vasodilatation. Changes in the activity of the $\mathrm{K}^{+}$ channels regulate the vascular tone.

The main $\mathrm{K}^{+}$channel subtypes consist of large and small conductance $\mathrm{Ca}^{2+}$-activated $\mathrm{K}^{+}$channels $\left(\mathrm{BK}_{\mathrm{Ca}}\right)$, which are selectively blocked by iberiotoxin and apamin, respectively. The $\mathrm{K}^{+}$channel group that appears to be involved in vascular tone regulation also includes ATPsensitive potassium channels, which are blocked by glibenclamide voltage-dependent channels $\left(\mathrm{K}_{\mathrm{v}}\right)$, which in turn are blocked by 4-aminopyridine and inward rectifier channels. The expression of these channels has been reported to vary among vessels of different sizes and vascular beds (33). However, the presence of $\mathrm{K}_{\mathrm{v}}$ and $\mathrm{BK}_{\mathrm{Ca}}$ channels has been demonstrated in all the vascular myocytes tested (34).

Altered function of $\mathrm{K}^{+}$channels is associated with hypertension, and $\mathrm{K}_{\mathrm{V}}$ and $\mathrm{BK}_{\mathrm{Ca}}$ are the most often studied channels involved in the vascular tone regulation. Increased vascular tone, a typical feature of most forms of hypertension, has been associated with impaired NO signaling. Although the main mechanism of vasodilatation induced by the ruthenium-derived $\mathrm{NO}$ donors is due to $\mathrm{K}^{+}$channel activation and membrane hyperpolarization in normotensive rat aorta, we have reported that none of the $\mathrm{K}^{+}$channel subtypes are activated by the $\mathrm{NO}$ donor trans-[RuCl([15] ane $\left.\mathrm{N}_{4}\right)_{\mathrm{NO}}{ }^{2+}$ in the aorta from renal hypertensive rats (35). These results demonstrate that in this model of hypertension, impaired $\mathrm{K}^{+}$channels can contribute to decreased vasodilatation in response to $\mathrm{NO}$.

\section{Vascular relaxation induced by the NO donors}

The new NO donors like trans-[RuCl([15]ane $\left.\mathrm{N}_{4}\right) \mathrm{NO}^{2+}$ (15-ane), [Ru(NH.NHq) (terpy) $\left.\mathrm{NO}^{+}\right]^{3+}$ (TERPY), cis-[RuCl (bpy)(2)(NO)](PF(6)) (RUNOCL), and sodium nitroprusside (SNP) induce relaxation in a concentration-dependent manner in denuded aortic rings pre-contracted with norepinephrine $(6,7)$. An illustration of this effect can be seen in Figure 2, which demonstrates the similar concentration dependent for all the new NO donors.

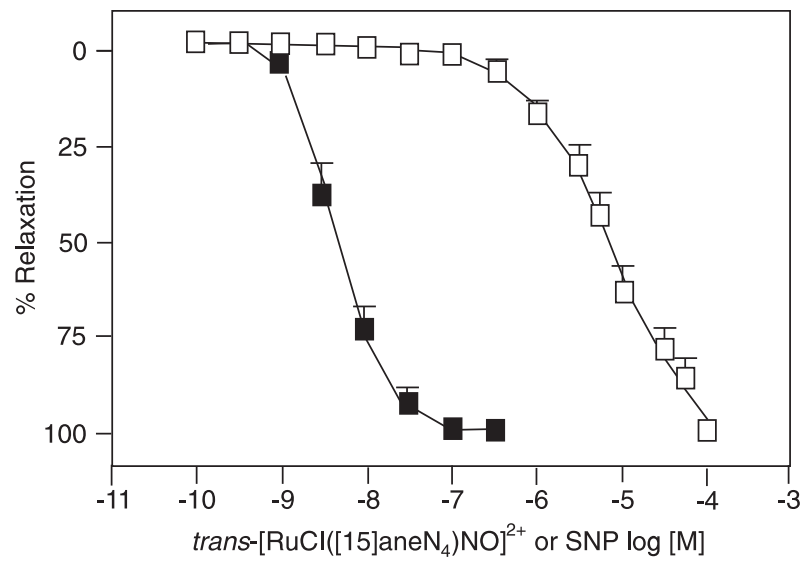

Figure 2. Effects of trans-[RuCl([15]aneN $\left.\mathrm{N}_{4}\right) \mathrm{NO}^{2+}$ and sodium nitroprusside (SNP) on rat thoracic aorta pre-contracted with norepinephrine. The arteries were pre-contracted with $0.1 \mu \mathrm{M}$ norepinephrine and trans- $\left[\mathrm{RuCl}\left([15] \mathrm{aneN}_{4}\right) \mathrm{NO}^{2+}\right.$ (open squares, $N=6$ ) or SNP (filled squares, $N=6$ ) was cumulatively added $(0.1 \mathrm{nM}$ to $100 \mu \mathrm{M}$ and $0.1 \mathrm{nM}$ to $0.3 \mu \mathrm{M}$, respectively). Data are reported as means \pm SEM of $\mathrm{N}$ experiments performed on preparations obtained from different animals. From Ref. 36 (with permission). 
$\mathrm{NO}$ released from all the NO donors is the common mediator that elicits their vasodilatory effects. The activation of guanylyl cyclase and accumulated cGMP lowers cytosolic $\mathrm{Ca}^{2+}$, leading to vasodilatation. Regarding the vascular relaxation induced by these new NO donors, all the new NO compounds induce vascular relaxation in a concentration-dependent way in denuded rat aortas precontracted with $0.1 \mu \mathrm{mol} / \mathrm{L}$ phenylephrine. The specificity of soluble guanyl cyclase activation should be different for the different NO donors. NO can exist in a variety of forms such as free radical and nitrosyl or nitronium ions, and its form depends on the NO source. Therefore, the NO released from NO donors can differ from the NO produced in endothelial cells. This could explain the differences in potency and efficacy of the known NO donors in inducing vasodilatation. The NO donor SNP also induces concentration-dependent relaxation, but it is more potent $\left(\mathrm{pD}_{2}\right.$ : $7.97 \pm 0.07, \mathrm{~N}=6)$ than 15 -ane $\left(\mathrm{pD}_{2}: 5.03 \pm 0.2, \mathrm{~N}=6\right)$, TERPY $\left(\mathrm{pD}_{2}: 6.47 \pm 0.13, \mathrm{~N}=6\right)$ and RUNOCL $\left(\mathrm{pD}_{2}: 6.62\right.$ $\pm 0.16, N=7$ ). In relation to the maximum relaxant effect, however, all the compounds induce a similar effect, as shown by $E_{\max }(105.86 \pm 3.34 \%, N=6$ for SNP; $98.35 \pm$ $1.22 \%, N=6$ for 15 -ane; $102.38 \pm 0.38 \%, N=6$ for TERPY, and $101.2 \pm 3.7 \%, \mathrm{~N}=7$ for RUNOCL). When mouse aorta relaxation is concerned, NO gas, spermine NONOate and Angeli's Salt are equipotent, with $\mathrm{pD}_{2}$ in the range of 6.0 . All these new NO donors display an important ability to induce vascular relaxation (36-40). The potency and efficacy of these NO donors and those of the authentic NO gas are comparable.

\section{Time-course of the relaxation induced by 15-ane, TERPY, RUNOCL, and SNP}

The time to reach the maximum relaxation has been evaluated for the new NO donors. Table 1 shows the values obtained in denuded aortic rings from normotensive rats. According to the structure and the particular

Table 1. Time to reach maximum relaxation of aorta ring induced by nitric oxide (NO) donors (modified Krebs solution, $37^{\circ} \mathrm{C}$, [NO donors] $=0.1 \mathrm{mmol} / \mathrm{L})$.

\begin{tabular}{lr}
\hline NO donor & Time (s) \\
\hline Sodium nitroprusside & 195 \\
TERPY & 255 \\
15-ane & 595 \\
RUNOCL & 1630 \\
\hline
\end{tabular}

TERPY $=\left[\mathrm{Ru}(\mathrm{NH} . \mathrm{NHq}) \text { (terpy) } \mathrm{NO}^{+}\right]^{3+} ; 15$-ane $=$ trans$\left[\mathrm{RuCl}\left([15] \mathrm{aneN}_{4}\right) \mathrm{NO}^{2+} ; \mathrm{RUNOCL}=\operatorname{cis}-[\mathrm{RuCl}(\mathrm{bpy})(2)(\mathrm{NO})]\right.$ (PF(6)). characteristics of each new NO donor such as extra/ intracellular release $(6,35-40)$, reduction potential (32), and light activation (6), the time course of the maximum relaxation can be modulated to a fast/slow event.

\section{Calcium measurements}

$\mathrm{NO}$ is an important regulator of vascular smooth muscle relaxation. It is well known that changes in the cytosolic calcium concentration $\left(\left[\mathrm{Ca}^{2+}\right]_{\mathrm{c}}\right)$ play a critical role in the relaxation of vascular smooth muscle cells (41). When activated by its second messenger cGMP, PKG modulates cellular function via phosphorylation of substrate proteins (42).

It has been shown that the mechanism of NO-dependent relaxation of the vascular smooth muscle cells involves a decrease in $\left[\mathrm{Ca}^{2+}\right]_{\mathrm{C}}$ by inhibition of $\mathrm{Ca}^{2+}$ entry (43). It has also been postulated that NO and cGMP may relax vascular smooth muscle cells by a cGMP-dependent $\mathrm{K}^{+}$channel activation (44). In the same way, a novel mechanism that operates by a direct effect of $\mathrm{NO}$ on $\mathrm{Ca}^{2+}$-dependent $\mathrm{K}^{+}$ channels (45) and L-type calcium current (44) and does not require cGMP has been demonstrated.

Studies on other types of smooth muscle preparations indicate that NO/cGMP may decrease $\left[\mathrm{Ca}^{2+}\right]_{\mathrm{c}}$ and reduce the sensitivity of contractile proteins to $\mathrm{Ca}^{2+}$, thereby resulting in the relaxation of smooth muscle.

Our confocal microscopy studies have shown that NO donors like 15-ane, TERPY and RUNOCL decrease $\left[\mathrm{Ca}^{2+}\right]_{\mathrm{c}}$ in the vascular smooth muscle cells. We have observed a decrease in $\left[\mathrm{Ca}^{2+}\right]_{\mathrm{C}}$ measured as fluorescence intensity of the $\mathrm{Ca}^{2+}$ sensitive dye Fluo-3AM after addition of the NO donors 15 -ane $(\% \Delta \mathrm{FI}: 14.1 \pm 3.5 \%, \mathrm{~N}=4)$, TERPY $(\% \Delta \mathrm{FI}$ : $55.7 \pm 4.8 \%, N=5)$, RUNOCL ( $\% \Delta \mathrm{FI}: 40.0 \pm 10.0 \%)$, and SNP (\% $\% \mathrm{FI}: 18.6 \pm 4.7 \%, N=4)(6,7,35)$. Among these new NO donors, TERPY leads to a more effective $\left[\mathrm{Ca}^{2+}\right]_{\mathrm{c}}$ reduction (Figure 3) $(6,40,46-49)$.

\section{Superoxide can contribute to reduced NO bioavailability and vascular relaxation in renal hypertensive rats}

It is well recognized that reactive oxygen species (ROS) play an important role in hypertension and in other cardiovascular diseases. Vascular cell types such as endothelial and vascular smooth muscle cells can produce ROS via cell membrane-associated $\mathrm{NAD}(\mathrm{P}) \mathrm{H}$ oxidase. ROS include superoxide $\left(\mathrm{O}_{2}^{-}\right)$, hydrogen peroxide and hydroxyl anion. Reactive nitrogen species such as $\mathrm{NO}$ and peroxynitrite are also biologically important $\mathrm{O}_{2}$ derivatives.

We have reported that relaxation induced by NO re- 


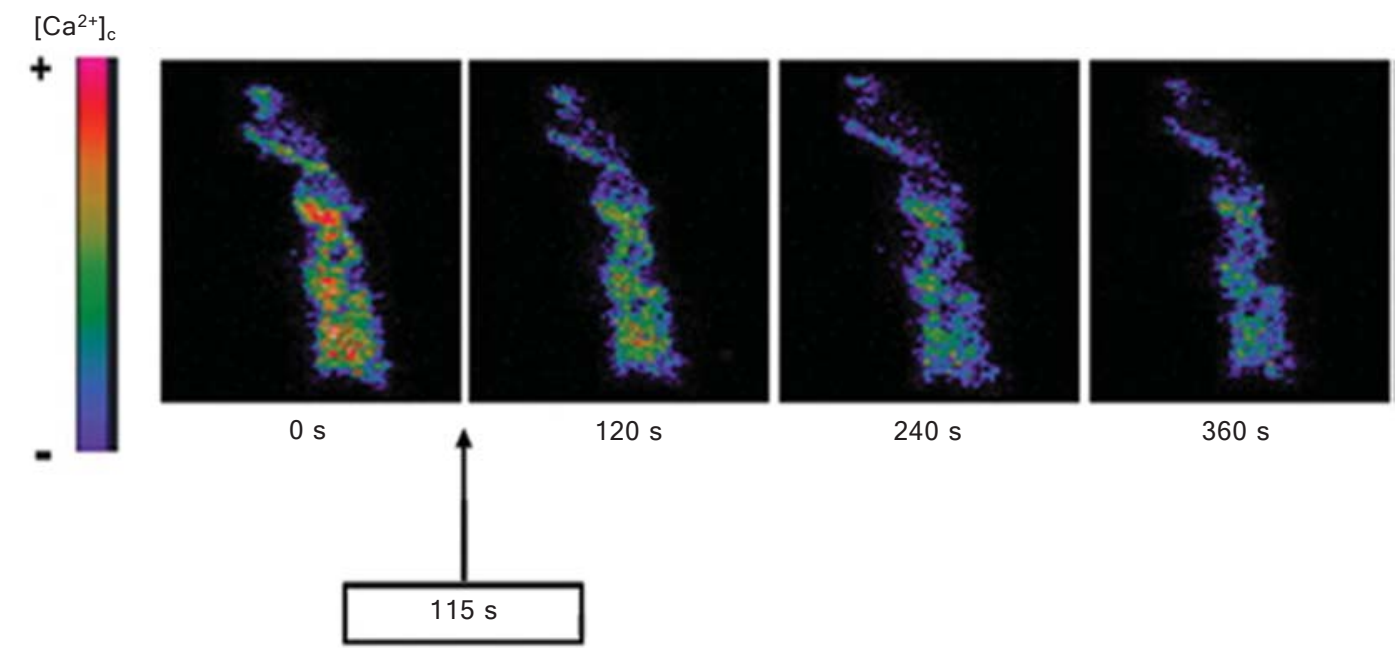

Figure 3. Decrease in cytosolic $\mathrm{Ca}^{2+}$ concentration $\left(\left[\mathrm{Ca}^{2+}\right]_{\mathrm{c}}\right)$ induced by $\left[\mathrm{Ru}(\mathrm{NH} . \mathrm{NHq})\left(\text { terpy) } \mathrm{NO}^{+}\right]^{3+}\right.$ (TERPY) in vascular smooth muscle cells from rat aortas. Cells were preloaded with Fluo-3AM $(10 \mu \mathrm{M})$ and stimulated with TERPY $(10 \mu \mathrm{M})$. Temporal effect of TERPY in a single vascular smooth muscle cell was recorded with a confocal microscope. TERPY was added after $115 \mathrm{~s}$. The intensity of the colors indicate higher $\left[\mathrm{Ca}^{2+}\right]_{\mathrm{C}}$ (as shown in the left bar). From Ref. 49 (with permission).

leased from the complexes TERPY and 15-ane is impaired in the aortic rings from $2 \mathrm{~K}-1 \mathrm{C}$ rats. This impairment has been attributed to increased ROS production. The impaired relaxation to TERPY in $2 \mathrm{~K}-1 \mathrm{C}$ aortic rings is normalized in the presence of the antioxidant agent vitamin $\mathrm{C}$. According to Oliveira-Sales et al. (50) the overactivity of $\mathrm{NAD}(\mathrm{P}) \mathrm{H}$ oxidase-derived ROS and lowered activity of CuZnSOD, an endogenous antioxidant, could contribute to $2 \mathrm{~K}-1 \mathrm{C}$ hypertension. These investigators have hypothesized that the increased angiotensin II characteristic of this hypertension model would activate $\mathrm{NAD}(\mathrm{P}) \mathrm{H}$ oxidase. An imbalance between ROS production and the antioxidant levels could lead to a significant increase in oxidative stress and hypertension.

We have shown that the basal cytosolic NO concentration $\left([\mathrm{NO}]_{\mathrm{C}}\right)$ is lower in $2 \mathrm{~K}-1 \mathrm{C}$ than in normotensive $(2 \mathrm{~K})$ aortic rings (49). After stimulation with the NO donor TERPY,
[NO $]_{\mathrm{C}}$ is also lower in $2 \mathrm{~K}$ compared with $2 \mathrm{~K}-1 \mathrm{C}$ aortic rings. These results indicate that NO bioavailability under basal conditions or bioavailability of NO released from TERPY is larger in the normotensive than in the renal hypertensive rat aorta.

\section{Concluding remarks}

NO released from the ruthenium complexes induces vascular smooth muscle relaxation via activation of cGMP production and $\mathrm{K}^{+}$channel activation in normotensive rat aorta, as well as decreased cytosolic $\mathrm{Ca}^{2+}$ concentrations. Vascular smooth muscle relaxation induced by the new $\mathrm{NO}$ donors is impaired in renal hypertensive rat aortas due to vascular dysfunction by decreased NO bioavailability and impaired $\mathrm{K}^{+}$channel activation.

\section{References}

1. Ignarro LJ, Cirino G, Casini A, Napoli C. Nitric oxide as a signaling molecule in the vascular system: an overview. $J$ Cardiovasc Pharmacol 1999; 34: 879-886.

2. Gruetter CA, Barry BK, McNamara DB, Gruetter DY, Kadowitz PJ, Ignarro L. Relaxation of bovine coronary artery and activation of coronary arterial guanylate cyclase by nitric oxide, nitroprusside and a carcinogenic nitrosoamine. J Cyclic Nucleotide Res 1979; 5: 211-224.
3. Feelisch M. Nitroxyl gets to the heart of the matter. Proc Natl Acad Sci U S A 2003; 100: 4978-4980.

4. Paolocci N, Katori T, Champion HC, St John M, Miranda $\mathrm{KM}$, Fukuto JM, et al. Positive inotropic and lusitropic effects of HNO/NO- in failing hearts: independence from betaadrenergic signaling. Proc Natl Acad Sci U S A 2003; 100: 5537-5542.

5. Ignarro LJ, Napoli C, Loscalzo J. Nitric oxide donors and 
cardiovascular agents modulating the bioactivity of nitric oxide: an overview. Circ Res 2002; 90: 21-28.

6. Bonaventura D, Lunardi CN, Rodrigues GJ, Neto MA, Bendhack LM. A novel mechanism of vascular relaxation induced by sodium nitroprusside in the isolated rat aorta. Nitric Oxide 2008; 18: 287-295.

7. Lunardi CN, Cacciari AL, Silva RS, Bendhack LM. Cytosolic calcium concentration is reduced by photolysis of a nitrosyl ruthenium complex in vascular smooth muscle cells. Nitric Oxide 2006; 15: 252-258.

8. Wang YX, Legzdins P, Poon JS, Pang CC. Vasodilator effects of organotransition-metal nitrosyl complexes, novel nitric oxide donors. J Cardiovasc Pharmacol 2000; 35: 7377.

9. Marcondes FG, Ferro AA, Souza-Torsoni A, Sumitani M, Clarke MJ, Franco DW, et al. In vivo effects of the controlled NO donor/scavenger ruthenium cyclam complexes on blood pressure. Life Sci 2002; 70: 2735-2752.

10. Fricker SP, Slade E, Powell NA, Vaughan OJ, Henderson GR, Murrer BA, et al. Ruthenium complexes as nitric oxide scavengers: a potential therapeutic approach to nitric oxidemediated diseases. Br J Pharmacol 1997; 122: 1441-1449.

11. Davies NA, Wilson MT, Slade E, Fricker SP, Murrer BA, Powell NA, et al. Kinetics of nitric oxide scavenging by ruthenium(III) polyaminocarboxylates: Novel therapeutic agents for septic shock. Chem Commun 1997; 47-48.

12. DeLeo MA, Ford PC. Photoreactions of coordinated nitrite ion. Reversible nitric oxide labilization from the chromium(III) complex [trans-Cr(cyclam)(ONO)2]+. Coord Chem Rev 2000; 208: 47-59.

13. Bourassa JL, Ford PC. Flash and continuous photolysis studies of Roussin's red salt dianion Fe2S2(NO)4/2- in solution. Coord Chem Rev 2000; 200-202: 887-900.

14. Ford PC, Ford PC. Photoreactivity of the ruthenium nitrosyl complex, Ru(salen)(Cl)(NO). Solvent effects on the back reaction of NO with the Lewis acid $\mathrm{Ru}(\mathrm{III})($ salen)(Cl) [1]. J Am Chem Soc 2000; 122: 7592-7593.

15. DeLeo MA, Bu X, Bentow J, Ford PC. The synthesis, characterization and structures of the chromium(III) dinitrito complexes: trans-[Cr(L)(ONO)2]+ $(\mathrm{L}=1,4,8,11$-tetraazacyclotetradecane or $5,7,7,12,14,14$-hexamethyl- 1,4,8,11-tetraazacyclotetradecane). Inorganica Chim Acta 2000; 300-302: 944-950.

16. Bourassa J, Lee B, Bernard S, Schoonover J, Ford PC. Flash photolysis studies of Roussin's black salt anion: $\mathrm{Fe}(4) \mathrm{S}(3)(\mathrm{NO})(7)(-)$. Inorg Chem 1999; 38: 2947-2952.

17. Tfouni E, Krieger M, McGarvey BR, Franco DW. Structure, chemical and photochemical reactivity and biological activity of some ruthenium amine nitrosyl complexes. Coord Chem Rev 2003; 236: 57-69.

18. Ford PC, Wink DA, Stanbury DM. Autoxidation kinetics of aqueous nitric oxide. FEBS Lett 1993; 326: 1-3.

19. Wink DA, Darbyshire JF, Nims RW, Saavedra JE, Ford PC. Reactions of the bioregulatory agent nitric oxide in oxygenated aqueous media: determination of the kinetics for oxidation and nitrosation by intermediates generated in the $\mathrm{NO} /$ $\mathrm{O}_{2}$ reaction. Chem Res Toxicol 1993; 6: 23-27.

20. Wink DA, Grisham MB, Mitchell JB, Ford PC. Direct and indirect effects of nitric oxide in chemical reactions relevant to biology. Methods Enzymol 1996; 268: 12-31.

21. Hutchings SR, Song D, Fricker SP, Pang CC. The ruthe- nium-based nitric oxide scavenger, AMD6221, augments cardiovascular responsiveness to noradrenaline in rats with streptozotocin-induced diabetes. Eur J Pharmacol 2005; 528: 132-136.

22. Zanichelli PG, Miotto AM, Estrela HF, Soares FR, GrassiKassisse DM, Spadari-Bratfisch RC, et al. The [Ru(Hedta) $\mathrm{NO}$ (0.1-) system: structure, chemical reactivity and biological assays. J Inorg Biochem 2004; 98: 1921-1932.

23. Wong SK, Garbers DL. Receptor guanylyl cyclases. J Clin Invest 1992; 90: 299-305.

24. Denninger JW, Marletta MA. Guanylate cyclase and the .NO/cGMP signaling pathway. Biochim Biophys Acta 1999; 1411: 334-350.

25. Anderson PG, Boerth NJ, Liu M, McNamara DB, Cornwell TL, Lincoln TM. Cyclic GMP-dependent protein kinase expression in coronary arterial smooth muscle in response to balloon catheter injury. Arterioscler Thromb Vasc Biol 2000; 20: 2192-2197.

26. Aitken A, Hemmings BA, Hofmann F. Identification of the residues on cyclic GMP-dependent protein kinase that are autophosphorylated in the presence of cyclic AMP and cyclic GMP. Biochim Biophys Acta 1984; 790: 219-225.

27. Chu DM, Francis SH, Thomas JW, Maksymovitch EA, Fosler M, Corbin JD. Activation by autophosphorylation or cGMP binding produces a similar apparent conformational change in cGMP-dependent protein kinase. J Biol Chem 1998; 273: 14649-14656

28. Zhuang D, Ceacareanu AC, Ceacareanu B, Hassid A. Essential role of protein kinase $G$ and decreased cytoplasmic $\mathrm{Ca}^{2+}$ levels in NO-induced inhibition of rat aortic smooth muscle cell motility. Am J Physiol Heart Circ Physiol 2005; 288: $\mathrm{H} 1859-\mathrm{H} 1866$.

29. Lincoln TM, Dey N, Sellak H. Invited review: cGMP-dependent protein kinase signaling mechanisms in smooth muscle: from the regulation of tone to gene expression. $J$ Appl Physiol 2001; 91: 1421-1430.

30. Si JQ, Zhao H, Yang Y, Jiang ZG, Nuttall AL. Nitric oxide induces hyperpolarization by opening ATP-sensitive $\mathrm{K}(+)$ channels in guinea pig spiral modiolar artery. Hear Res 2002; 171: 167-176.

31. Kuriyama $\mathrm{H}$, Kitamura $\mathrm{K}$, Nabata $\mathrm{H}$. Pharmacological and physiological significance of ion channels and factors that modulate them in vascular tissues. Pharmacol Rev 1995; 47: 387-573.

32. Edwards G, Weston AH. Structure-activity relationships of K+ channel openers. Trends Pharmacol Sci 1990; 11: 417422.

33. Michelakis ED, Reeve HL, Huang JM, Tolarova S, Nelson DP, Weir EK, et al. Potassium channel diversity in vascular smooth muscle cells. Can J Physiol Pharmacol 1997; 75: 889-897.

34. Nelson MT, Quayle JM. Physiological roles and properties of potassium channels in arterial smooth muscle. Am J Physiol 1995; 268: C799-C822.

35. Bonaventura D, Oliveira FS, da Silva RS, Bendhack LM. Decreased vasodilation induced by a new nitric oxide donor in two kidney, one clip hypertensive rats is due to impaired $\mathrm{K}$ channel activation. Clin Exp Pharmacol Physiol 2005; 32: 478-481.

36. Bonaventura D, de S Oliveira, Togniolo V, Tedesco AC, da Silva RS, Bendhack LM. A macrocyclic nitrosyl ruthenium 
complex is a NO donor that induces rat aorta relaxation. Nitric Oxide 2004; 10: 83-91.

37. Bonaventura D, de Lima RG, Vercesi JA, da Silva RS, Bendhack LM. Comparison of the mechanisms underlying the relaxation induced by two nitric oxide donors: sodium nitroprusside and a new ruthenium complex. Vascul Pharmacol 2007; 46: 215-222.

38. de Lima RG, Sauaia MG, Bonaventura D, Tedesco AC, Bendhack $L M$, da Silva $R$. Influence of ancillary ligand $L$ in the nitric oxide photorelease by the $[\mathrm{Ru}(\mathrm{L})(\mathrm{tpy}) \mathrm{NO}]\left(3^{+}\right) \mathrm{com}-$ plex and its vasodilator activity based on visible light irradiation. Inorganica Chim Acta 2006; 359: 2543-2549.

39. Lunardi CN, Vercesi JA, da Silva RS, Bendhack LM. Vasorelaxation induced by the new nitric oxide donor cis- $[\mathrm{Ru}(\mathrm{Cl})$ (bpy)(2)(NO)](PF(6)) is due to activation of $\mathrm{K}(\mathrm{Ca})$ by a cGMP-dependent pathway. Vascul Pharmacol 2007; 47: 139-144.

40. Oliveira FS, Ferreira KQ, Bonaventura D, Bendhack LM, Tedesco AC, Machado SP, et al. The macrocyclic effect and vasodilation response based on the photoinduced nitric oxide release from trans-[RuCl(tetraazamacrocycle) NO] $\left({ }^{2+}\right.$ ). J Inorg Biochem 2007; 101: 313-320.

41. Li PL, Lee HC, Nelson MT, Meininger GA, Van Breemen C. Novel $\mathrm{Ca}^{2+}$ signalling mechanisms in vascular myocytes: symposium overview. Acta Physiol Scand 2003; 179: 339352.

42. Soloviev A, Lehen'kyi V, Zelensky S, Hellstrand P. Nitric oxide relaxes rat tail artery smooth muscle by cyclic GMPindependent decrease in calcium sensitivity of myofilaments. Cell Calcium 2004; 36: 165-173.

43. Summers BA, Overholt JL, Prabhakar NR. Nitric oxide inhibits L-type $\mathrm{Ca}^{2+}$ current in glomus cells of the rabbit ca- rotid body via a cGMP-independent mechanism. J Neurophysiol 1999; 81: 1449-1457.

44. Archer SL, Huang JM, Hampl V, Nelson DP, Shultz PJ, Weir EK. Nitric oxide and cGMP cause vasorelaxation by activation of a charybdotoxin-sensitive $\mathrm{K}$ channel by cGMP-dependent protein kinase. Proc Natl Acad Sci U S A 1994; 91: 7583-7587.

45. Bolotina VM, Najibi S, Palacino JJ, Pagano PJ, Cohen RA. Nitric oxide directly activates calcium-dependent potassium channels in vascular smooth muscle. Nature 1994; 368: 850-853.

46. Bonaventura D, Oliveira FS, Lunardi CN, Vercesi JA, da Silva RS, Bendhack LM. Characterization of the mechanisms of action and nitric oxide species involved in the relaxation induced by the ruthenium complex. Nitric Oxide 2006; 15: 387-394.

47. Bonaventura D, Lunardi CN, Rodrigues GJ, Neto MA, de Lima RG, da Silva RS, et al. Endothelium modulates the vascular relaxation induced by the nitric oxide donor. Basic Clin Pharmacol Toxicol 2008; 102: 38-39.

48. Rodrigues GJ, Restini CB, Lunardi CN, Moreira JE, Lima $R G$, da Silva RS, et al. Caveolae dysfunction contributes to impaired relaxation induced by nitric oxide donor in aorta from renal hypertensive rats. J Pharmacol Exp Ther 2007; 323: 831-837.

49. Rodrigues GJ, Lunardi CN, Lima RG, Santos CX, Laurindo FR, da Silva RS, et al. Vitamin C improves the effect of a new nitric oxide donor on the vascular smooth muscle from renal hypertensive rats. Nitric Oxide 2008; 18: 176-183.

50. Oliveira-Sales EB, Dugaich AP, Carillo BA, Abreu NP, Boim $M A$, Martins PJ, et al. Oxidative stress contributes to renovascular hypertension. Am J Hypertens 2008; 21: 98-104. 